Edi Maletić

Darko Preiner

Jasminka Karoglan Kontić

Silvio Šimon

Ivan Pejić
UDK: 634.8:582.783

DOI: http://doi.org/10.21857/mnlqgcj8jy

Pregledni članak

Rukopis prihvaćen za tisak: 14.9.2016.

\title{
ISTRAŽIVANJA UNUTARSORTNE VARIJABILNOSTI VINOVE LOZE U HRVATSKOJ I KLONSKA SELEKCIJA
}

\section{Sažetak}

U Hrvatskoj se tradicionalno uzgaja veliki broj sorata vinove loze, od kojih se većina smatra autohtonima. Kako do sada nije provedena sustavna selekcija autohtonih sorata, pretpostavlja se da je danas kod većine njih izražena visoka razina unutarsortne varijabilnosti. Naime, poznato je da kod dugotrajnog uzgoja neke sorte vinove loze (Vitis vinifera L.) bez sustavne selekcije unatoč vegetativnom razmnožavanju dolazi do pojave izražene unutarsortne varijabilnosti. Najčešće je tome razlog pojava mutacija koje mogu pozitivno ili negativno utjecati na gospodarski važna svojstva sorata vinove loze. Klonska selekcija je postupak kojim se nastoje izdvojiti genotipovi unutar sorte kod kojih je došlo do mutacija, a koje su rezultirale u pozitivnoj promjeni nekih od gospodarski važnih svojstava. Provođenje selekcije nužan je preduvjet za proizvodnju kvalitetnog sadnog materijala poboljšanih sortnih svojstava i garantirane zdravstvene čistoće. Znanstvena istraživanja unutarsortne varijabilnosti i unaprjeđenje metoda klonske selekcije mogu znatno doprinijeti razvoju vinogradarske proizvodnje, a posredno su važni i za očuvanje genetskih resursa vinove loze. To je posebno važno za zemlje bogate autohtonim sortama, čime se potiče i njihova gospodarska revitalizacija. U ovom radu daje se pregled metoda i istraživanja unutarsortne varijabilnosti posljednjih godina, kao i oplemenjivanja sorata vinove loze kroz sustav klonske selekcije. Posebna pozornost usmjerena je na istraživanja hrvatskog sortimenta posljednjih desetak godina, a prikazani rezultati ukazuju na visoku razinu unutarsortne varijabilnosti kod većine sorata te potrebu provedbe klonske selekcije.

Ključne riječi: unutarsortna varijabilnost vinove loze; klonska selekcija; autohtone sorte. 


\section{Unutarsortna varijabilnost kod vinove loze}

Vinova loza (Vitis vinifera L.) jedna je od najzastupljenijih i najduže uzgajanih višegodišnjih kultura u svijetu. Zbog dugoga razdoblja uzgoja vinove loze došlo je do velike divergentnosti koja se očituje u nastajanju velikog broja novih sorata (najviše spontanim križanjima), ali i brojnim mutacijama unutar njihovih populacija.

Sorte vinove loze nastaju generativno, kao rezultat oplodnje, a zatim se održavaju aseksualno, reprodukcijom pomoću vegetativnih dijelova biljke čime se svojstva majke vjerno prenose na potomstvo. Većina višegodišnjih poljoprivrednih kultura (posebno vinova loza i voćne vrste) se za potrebe poljoprivredne proizvodnje razmnožavaju vegetativno, pupovima ili reznicama, što se još naziva i kloniranje. Tako su sve jedinke neke sorte rezultat višekratnog vegetativnog razmnožavanja (kloniranja) prve, ishodišne biljke koja se razvila iz sjemenke (Maletić i sur., 2008.). Iz ovoga proizlazi da bi sve jedinke neke sorte trebale biti genetički uniformne (identičnog genotipa), međutim, u okviru populacija sorata pojavljuju se biljke koje po svojem fenotipu odstupaju od prosjeka populacije. Tipična svojstva neke sorte mogu u manjoj ili većoj mjeri varirati u svojoj veličini i intenzitetu zbog utjecaja okoline, tj. mjesta uzgoja i vremenskih prilika odnosno skupa biotskih i abiotskih faktora.

Brojni autori (Botta i sur., 1995; Moreno i sur., 1998; Boso Alonso i sur., 2004.) navode kako unutar sorata vinove loze postoji određena varijabilnost. Regner i sur. (2000.) navodi kako postoje bitne razlike u unutarsortnoj varijabilnosti između različitih sorata, a kao jedan od glavnog razloga velike varijabilnosti kod sorata iz grupe Pinot-a navodi njihovu starost i široku rasprostranjenost.

Preduvjet za razvoj unutarsortne varijabilnosti jest dugotrajno vegetativno razmnožavanje neke sorte. Način na koji se ekstenzivno razmnožavaju autohtone sorte bez sustavne selekcije također doprinosi akumulaciji većeg broja mutacija, kao i dugotrajna prostorna izoliranost neke sorte. Tako je Wolpert i sur. (1994.) utvrdio jasne razlike između talijanskog klona Primitiva i klonova iste sorte (pod imenom Zinfandel) podrijetlom iz Kalifornije, kao i unutar klonova Zinfandela iz Kalifornije.

Uzgojem vinove loze $\mathrm{u}$ istim uvjetima (ex situ eksperimentalni vinogradi, ujednačena agrotehnika i sl.) smanjuje se utjecaj okoline na ekspresiju svojstava (svi klonovi imaju iste okolinske uvjete), a odgovarajućim eksperimentalnim dizajnom samih vinograda omogućuje se i odgovarajuća statistička analiza kojom je moguće razdvojiti utjecaj okoline i utjecaj genotipa (klona) na ispitivana svojstva. Unutarsortna varijabilnost kod klonskih sorata može biti uzrokovana i zbog prisutnosti fitopatogenih organizama (virusa i viroida), kao i epigenetskim promjenama na molekuli DNA. Međutim, kod sorata koje se dugo uzgajaju najveći izvor unutarsortne varijabilnosti su mutacije (Mullins i sur., 1992., Cindrić, 2003.). 


\section{Klonska selekcija}

Klonska selekcija dobila je naziv jer se provodi izborom klonova tj. vegetativnog potomstva koje pripada istoj sorti. Klonska selekcija danas je najvažniji način oplemenjivanja vinove loze. Naime zbog teškog uvođenja novih sorata na neko područje, u velikoj mjeri uvjetovanog favoriziranjem tradicionalnih (tzv. starih) sorata od strane potrošača, oplemenjivanjem se nastoje poboljšati postojeće sorte. Klonska selekcija temelji se na unutarsortnoj varijabilnosti, kao posljedici akumuliranja mutacija tijekom dugotrajnog vegetativnog razmnožavanja. Dugotrajnom propagacijom bez sustavne selekcije sorta gubi proizvodni potencijal odnosno gubi neke značajke koje karakteriziraju određenu sortu zbog pojave i akumulacije mutacija koje mogu biti pozitivne i negativne.

Klonska selekcija postupak je kojim se iz populacije sorte izdvajaju trsovi (potencijalni klonovi) kod kojih uočavamo pozitivne promjene nekog od gospodarski važnih svojstava. Klonska selekcija podrazumijeva usporednu genetičku i zdravstvenu selekciju.

\section{Mutacije i genetička selekcija}

Genetička selekcija osnova je klonske selekcije kojoj je cilj izdvajanje i razmnožavanje pozitivnih mutanata te njihovo uvođenje u proizvodnju sa statusom klona. Mutacije gena ili genoma nasljedne su promjene u strukturi DNA, a najčešće se ogledaju u zamjeni pojedinih parova baza u originalnom lancu DNA (točkaste mutacije) ili umetanju i brisanju dijelova DNA lanca (delecije i translokacije). Još nedovoljno istraženu ulogu u nastanku mutacija imaju tzv. pokretni elementi (transpozoni), segmenti DNA koji imaju sposobnost kretanja ili multipliciranja unutar genoma stvarajući svoje višestruke kopije u regijama nerepetitivne DNA, te kao takvi mogu dovesti do prekida kromosoma, inaktivacije gena, povećanja genoma, izmjene dijelova originalne sekvence DNA i sl., a što može imati vrlo različite posljedice na fenotipu (Maletić i sur., 2008.).

Jedan od principa evolucijske biologije kaže da pojavu mutacija nije moguće potpuno spriječiti (King, 2011.), a frekvencija mutacija kod višegodišnjih vrsta još uvijek nije poznata. Zna se da drvenaste vrste evoluiraju sporije nego jednogodišnje zeljaste biljke (Pelsy, 2010.), a prema nekim autorima (Galet, 2000.) učestalost spontanih mutacija kod vinove loze relativno je niska i iznosi $10^{-6}$ do $10^{-8}$. Mutacije mogu s općeg biološkog i agronomskog stajališta biti i negativne i pozitivne, a dovode do pojave unutarsortne genetičke varijabilnosti, te su temelj za prirodnu (evolucija) i umjetnu selekciju (razvoj novih genotipova - klonova) (Maletić i sur., 2008.). Za potrebe rasadničarske i vinarske industrije homogenost unutar sorte je vrlo važna, a moguć- 
nost procjene unutarsortne varijabilnosti, selekcije različitih novih klonova kao i karakterizacije i identifikacije postojećih klonova unutar sorte je pri tom vrlo važna (Carimi i sur., 2011.).

Mutacije su glavna pretpostavka i osnova uspjeha klonske selekcije, metode koja je široko prihvaćena kao način održavanja i poboljšanja afirmiranih tradicionalnih sorata. Osim toga, mutacije je moguće inducirati mutagenim agensima i na taj način povećati frekvenciju mutanata te tako stvoriti pretpostavku za učinkovitiju selekciju.

\section{Zdravstvena selekcija}

Zdravstvena selekcija provodi se kako bi dobili virusno čisti sadni materijal. Zdravstvena selekcija (izbor zdravih klonova) provodi se usporedno s genetičkom selekcijom (izbor pozitivnih mutanata). Ona podrazumijeva odabiranje zdravih trsova tj. detekciju i proučavanje simptoma bolesti što ih uzrokuju virusi ili virusima slični organizmi koji se prenose vegetativnim razmnožavanjem koji negativno utječu na proizvodne osobine sorata, a ujedno i doprinose povećanju fenotipske varijabilnosti unutar populacije vinove loze.

Prije razmnožavanja odabrani trsovi se provjeravaju na prisutnost uzročnika virusnih i virusima sličnih bolesti vinove loze. S obzirom na zahtjevnost i visoke troškove testiranja, u postupku certifikacije kontroliraju se one bolesti koje uzrokuju najveću gospodarsku štetu.

Da bi sadni materijal imao status „virus free“ prema važećim zakonskim propisima (NN 133/2006) ELISA testovi moraju biti negativni na ove viruse: GFLV (Grapevine Fanleaf Virus) - virus lepezastog lista vinove loze GLRaV-1 i 3 (Grapevine Leafroll associated Virus) i virus mozaika gušarke ArMV (Arabis Mosaic Virus).

Indeksiranje i testovi ELISA provode se po preporučenoj shemi OIV-a (Međunarodne organizacije za lozu i vino). ELISA testiranje i indeksiranje obavlja ovlaštena stručna ili znanstvena institucija, koja ovisno o rezultatima testiranja izdaje zdravstvenu potvrdu (certifikat).

\section{Unutarsortna varijabilnost i klonska selekcija autohtonih sorata u Hrvatskoj}

Autohtone sorte vinove loze imaju vrlo bitnu ulogu u vinogradarstvu Republike Hrvatske, a posebno za područje Dalmacije. Ukupne površine pod vinogradima u Hrvatskoj iznose oko 26.000 ha, a od najvažnijih 30 sorata na tim površinama njih 15 smatra se autohtonima. Znatan je i porast udjela autohtonih sorata pri podizanju novih nasada, tj. u proizvodnji sadnog materijala koji je s 21,6\% u 2004. godini porastao na 37,8\% u 2010. godini (Preiner, 2012.). Unatoč nizu pozitivnih aspekata naglog povećanja udjela autohtonog sortimenta, u ukupnoj vinogradarskoj proizvod- 
nji Hrvatske postoji problem kvalitete sadnog materijala koji je kod svih autohtonih sorata najniže kvalitativne kategorije „standard“. Zbog velike potražnje za sadnim materijalom autohtonih sorata, plemke za njihovu proizvodnju često su uzimane iz proizvodnih nasada, bez prethodno provedenih selekcijskih postupaka.

Istraživanjima koja su provedena na autohtonom sortimentu u zadnjih 10-ak godina utvrđena je izuzetno visoka zaraženost gospodarski štetnim virusima u njihovoj populaciji (Karoglan Kontić i sur., 2009a., 2009b., Poljuha i sur., 2010.) (Tablica 1) Zabrinjava i činjenica kako se svi ovi rezultati odnose samo na one trsove koji nisu pokazivali vizualne simptome viroza, tj. odabrane u postupku pozitivne masovne selekcije. To znači da bi infekcija virusima u ukupnoj populaciji sorata mogla biti i veća od detektirane, pa tako i u sadnom materijalu koji se proizvodi bez selekcije. Navedenim istraživanjem obuhvaćeni su virusi čija prisutnost nije dopuštena u certificiranom sadnom materijalu: GFLV (Grapevine fanleaf virus), ArMaV (Arabis mosaic virus), GLRaV-1 i GLRaV-3 (Grapevine leafroll virus 1 and 3). Kod najbitnijih autohtonih sorata utvrdena je i visoka razina unutarsortne varijabilnosti kao posljedica akumulacije pozitivnih i negativnih mutacija (Preiner, 2012., Preiner i sur., 2012., Zdunić i sur., 2007., 2012.).

Tablica 1: Rezultati sanitarnog statusa 13 hrvatskih autohtonih sorata vinove loze uključenih u postupak klonske selekcije na temelju odabranih trsova u postupku masovne pozitivne selekcije

\begin{tabular}{|c|c|c|c|c|c|}
\hline Sorta & $\begin{array}{l}\text { Vinogradarska } \\
\text { regija }\end{array}$ & $\begin{array}{c}\text { Broj analiziranih } \\
\text { trsova }\end{array}$ & $\begin{array}{l}\text { Broj zdravih } \\
\text { trsova* }\end{array}$ & $\begin{array}{c}\text { Broj zaraženih } \\
\text { trsova }\end{array}$ & $\begin{array}{c}\% \text { zdravih } \\
\text { trsova }\end{array}$ \\
\hline Graševina & \multirow{4}{*}{ Kontinentalna } & 269 & 140 & 129 & 52,0 \\
\hline Kraljevina & & 184 & 121 & 63 & 65,8 \\
\hline Moslavac & & 142 & 79 & 63 & 55,6 \\
\hline Škrlet & & 76 & 11 & 65 & 14,5 \\
\hline Babić & \multirow{9}{*}{ Primorska } & 87 & 0 & 87 & 0,0 \\
\hline Debit & & 95 & 18 & 77 & 18,9 \\
\hline Grk & & 69 & 37 & 32 & 53,6 \\
\hline Maraština & & 135 & 7 & 128 & 5,2 \\
\hline Plavac mali & & 545 & 32 & 513 & 5,9 \\
\hline Plavina & & 111 & 67 & 44 & 60,4 \\
\hline Pošip & & 125 & 19 & 106 & 15,2 \\
\hline Vugava & & 127 & 10 & 117 & 7,9 \\
\hline Žlahtina & & 136 & 53 & 83 & 39,0 \\
\hline \multicolumn{2}{|l|}{ Ukupno } & 2032 & 557 & 1475 & 27,4 \\
\hline
\end{tabular}

* Analizirana je prisutnost 4 gospodarski najštetnija virusa čija prisutnost nije dopuštena u certificiranom sadnom materijalu: GFLV (Grapevine fanleaf virus), ArMaV (Arabis mosaic virus), GLRaV-1 i GLRaV-3 (Grapevine leafroll virus 1 i 3) a u zaraženim uzorcima utvrđen je najmanje jedan od navedenih virusa. 
$\mathrm{S}$ obzirom na veliku važnost autohtonih sorata vinove loze u vinogradarskoj proizvodnji nužno je hitno provođenje postupaka klonske selekcije čime se jedino može osigurati zdrav i kvalitetan sadni materijal ovih sorata, spriječiti daljnje širenje gospodarski štetnih virusa te izdvojiti klonove kod najbitnijih sorata kako bi se omogućilo vinogradarima da odabirom klona pojedine sorte unaprijede svoju proizvodnju. Kako je individualna klonska selekcija dugotrajan proces koji obično traje od 18-25 godina, a i zbog očite potrebe za poboljšanjem kvalitete sadnog materijala autohtonih sorata, pokrenuta su istraživanja u sklopu znanstvenog projekata "Unutarsortna raznolikost vinove loze i unaprjeđenje klonske selekcije“ (Ministarstvo znanosti, obrazovanja i sporta, 2007. - 2012.). Nositelj projekta bio je Agronomski fakultet Sveučilišta u Zagrebu, a glavni cilj bio je da se primjenom novih analitičkih postupaka ubrza i poveća učinkovitost klonske selekcije autohtonih hrvatskih sorata vinove loze.

U Hrvatskoj do sada nije bilo sustavnog provođenja klonske selekcije autohtonih sorata vinove loze, kao ni ustanove kojoj bi zadaća bila održavanje visokih kvalitativnih kategorija dobivenih selekcijom. Najveći dio autohtonih sorata vinove loze povezuje se s područjem Dalmacije gdje su one osnova vinogradarsko vinarske proizvodnje. Sve navedeno je kod autohtonog sortimenta na području Dalmacije rezultiralo visokim stupnjem zaraženosti gospodarski štetnim virozama, otežanom proizvodnjom sadnog materijala - nepostojanje matičnjaka plemki za proizvodnju kvalitetnog repromaterijala i visokom razinom unutarsortne varijabilnosti kao posljedice akumulacije pozitivnih i negativnih mutacija u populaciji pojedinih sorata.

Ukupno gledajući stanje na tržištu sadnog materijala vinove loze u Hrvatskoj zadnjih 10-ak godina, a i više, može se uočiti kako preko $70 \%$ ukupno proizvedenih cjepova spada u kategoriju standard (žuta ili narančasta etiketa), što je najniža razina kvalitete koja uglavnom nije prošla ni masovnu klonsku selekciju i nije testirana na prisutnost virusa. Samo 30\% svih cjepova iz tog razdoblja certificirani je sadni materijal, a samo jedan manji dio od toga su selekcionirani klonovi. Što se autohtonih sorata tiče, sav certificirani materijal koji se zadnjih godina pojavljuje na hrvatskom tržištu sadnog materijala rezultat je ovih istraživanja, a prve klonove očekujemo u idućih nekoliko godina.

\section{Zaključak}

Istraživanja unutarsortne varijabilnosti i klonska selekcija hrvatskih autohtonih sorata vrlo su važni za budući razvoj vinogradarstva. Ovi se postupci i istraživanja provode $\mathrm{u}$ svim razvijenim vinogradarskim zemljama svijeta, kako bi unaprijedile proizvodnju grožđa i vina. Znanstvenim radom na ovoj problematici može se znatno utjecati na sortne performanse, pa je u direktnoj vezi s rentabilnošću same proi- 
zvodnje. Kako su ove aktivnosti usko povezane i s rasadničkom proizvodnjom, vrlo su važne i zbog očuvanja i revitalizacije autohtonih sorata, koje su u pravilu ugrožene nekontroliranim širenjem internacionalnih sorata. Na taj se način podupire i zaštita malih populacija, koje još nisu uključene u sustav očuvanja genetskih resursa, a što je od posebne važnosti za zemlje bogate autohtonom germplazmom vinove loze i koje prilagođavaju svoje propise EU zakonodavstvu.

\section{Litaratura}

Boso Alonso, S. Santiago, J. L., Martzinez, M. (2004). Intravarietal Agronomic Variability in Vitis vinifera L. cv. Albariño. American Journal of Enology and Viticulture 55(3): 279-282.

Botta, R., Scott, N.S., Eynard, I., Thomas, M.R. (1995). Evaluation of Microsatellite Sequence-tagged markers for characterising Vitis vinifera Cultivars. Vitis 34(2): 99-102.

Carimi, F., Mercati, F., De Michele, R., Carola Fiore, M., Riccardi, P., Sunseri, F. (2011). Intra-varietal genetic diversity of the grapevine (Vitis vinifera L.) cultivar 'Nero d' Avola' as revealed by microsatellite markers.

Cindrić, P., (2003). Klonska selekcija. Savremena poljoprivreda. vol. 52, Novi Sad.

Galet, P. (2000). General viticulture, $2^{\text {nd }}$ edition, Avenir Oenologie, Oenoplurimédia - Sveučilište Cornell.

Karoglan Kontić, J., Pejić, I., Maletić, E., Sladonja, B., Vokurka, A., Zdunić, G., Preiner, D., Šimon, S. and E. Ruehl. (2009a).Virus diseases screening in clonal selection of Croatian grapevine cultivars. Acta Horticulturae (ISHS). 827: 623-626.

Karoglan Kontić, J., Preiner, D., Šimon, S., Zdunić, G., Poljuha, D., Maletić, E. (2009b). Sanitary Status of Croatian Native Grapevine Variaties. Agriculturale Conspectus Scientificus. 74(2):1-5.

King, D.G. (2011). Evolution of simple sequence repeats as mutable sites. U: Tandem Repeat Polymorphism: Genetic Plasticity, Neural DIversity and Disease. Landes Bioscience and Springer Science+Bussiness Media.

Maletić, E., Karoglan Kontić, J., Pejić, I. (2008). Vinova loza - ampelografija, ekologija, oplemenjivanje. Školska knjiga, Zagreb.

Moreno, S., Martin, J.P., Ortiz, J.M. (1998). Inter-simple sequence repeats PCR for characterization of closly related grapevina gremplasm. Euphytica 101: 117-125.

Mullins M.G., Bouquet A., Williams L.E. (1992). Biology of the grapevine. Cambridge University Press, Cambridge, New York, Melbourne.

Pelsy, F. (2010). Molecular and cellular mechanisms of diversity within grapevine varieties. Heredity 104, 331-340. 
Poljuha, D., Sladonja, B., Bubola, M., (2010). Incidence of viruses infecting grapevine varieties in Istria (Croatia). Journal of Food Agriculture and Environment. 8:166-169.

Preiner, D., Karoglan Kontić, J., Šimon, S., Marković, Z., Stupić, D., Maletić, E. (2012). Intravarietal Agronomic Variability in Croatian Native Vitis vinifera L. Cultivar Grk with Female Flower and Seedles Berries. American Journal of Enology and Viticulture 63(2):291-295.

Preiner, D. (2012). Učinkovitost masovne pozitivne selekcije unutar populacija autohtonih sorata vinove loze (V. vinifera L.) u Dalmaciji, Doktorska disertacija, Sveučilište u Zagrebu, Agronomski fakultet.

Regner, F., Stadlbauer, A., Eisenheld, C., Kaserer, H. (2000). Genetic Relationship Among Pinots and Related Cultivars. American Journal of Enology and Viticulture 51(1): 7-14.

Wolpert, J. A., Kasimati, A. N., Weber, E. (1994). Field Performance of six Chardonnay Clones in the Napa Valey. American Journal of Viticulture and Enology 45(4): 393-40.

Zdunić, G., Maletić, E., Vokurka, A., Karoglan Kontić, J., Pezo, I., Pejić, I. (2007). Phenotypical, sanitary and ampelometric variability within the population of $\mathrm{cv}$. Plavac mali (Vitis vinifera L.). Agriculturae Conspectus Scientificus 72: 117-128.

Zdunić, G., S. Šimon, N. Malenica, D. Preiner, E. Maletić, I. Pejić (2012). Morphometric and molecular analysis of a pink-berried mutant within the population of grape cultivar 'Plavac mali'. Vitis, 51: 7-13.

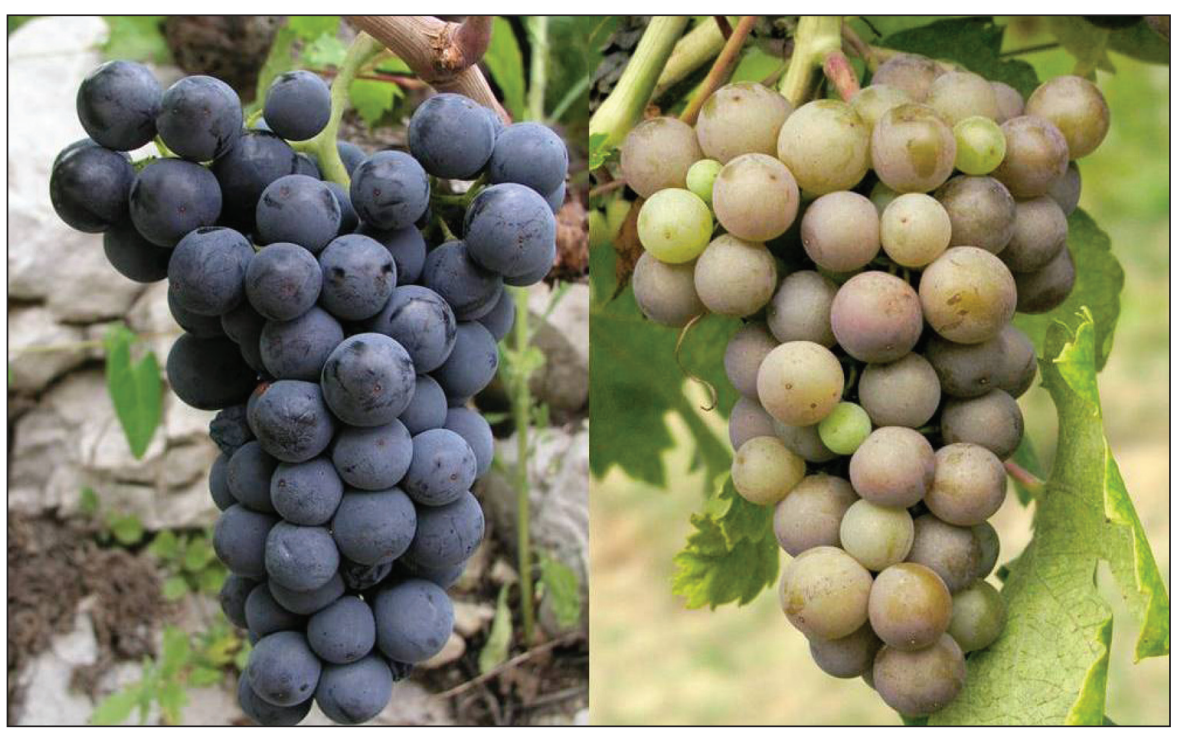

Slika 1: Plavac mali - mutacija boje kožice (PM crni : PM sivi); 
Radovi Zavoda za znanstveni i umjetnički rad u Požegi, br. 5 (2016), str. 1-11

E. Maletić, D. Preiner, J. Karoglan Kontić, S. Simon, I. Pejić: Istrživanja unutarsortne varijabilnosti...

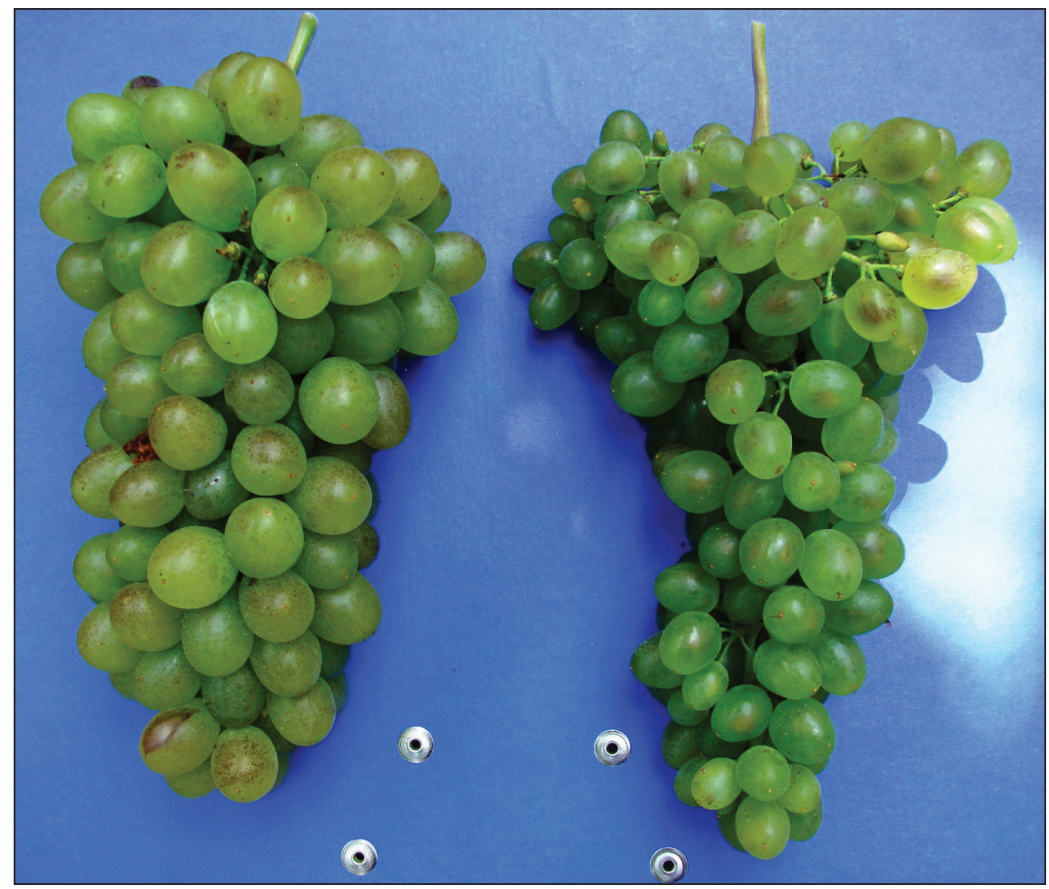

Slika 2: Pošip bijeli - klonski kandidati s različitim karakteristikama grozda;

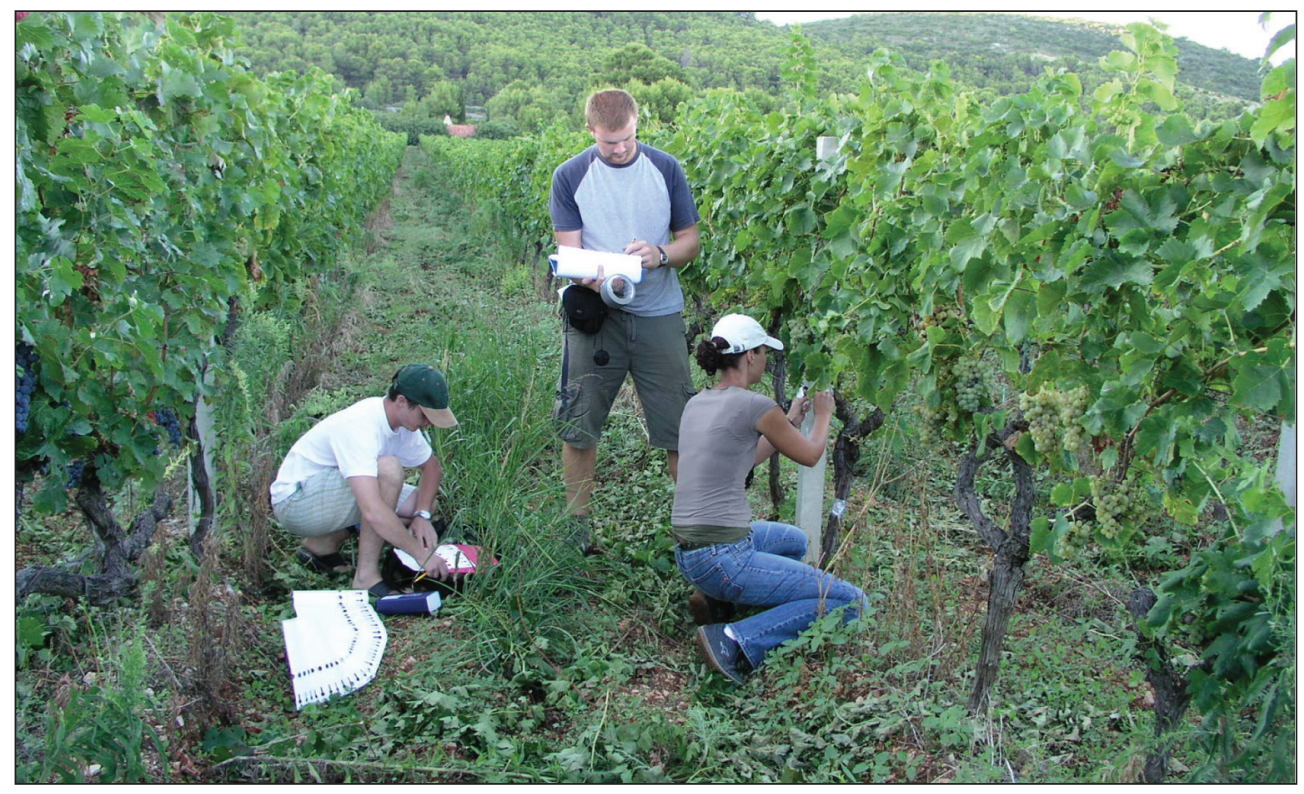

Slika 3: Pozitivna masovna selekcija - izbor klonskih kandidata; 
Radovi Zavoda za znanstveni i umjetnički rad u Požegi, br. 5 (2016), str. 1-11

E. Maletić, D. Preiner, J. Karoglan Kontić, S. Simon, I. Pejić: Istrživanja unutarsortne varijabilnosti...

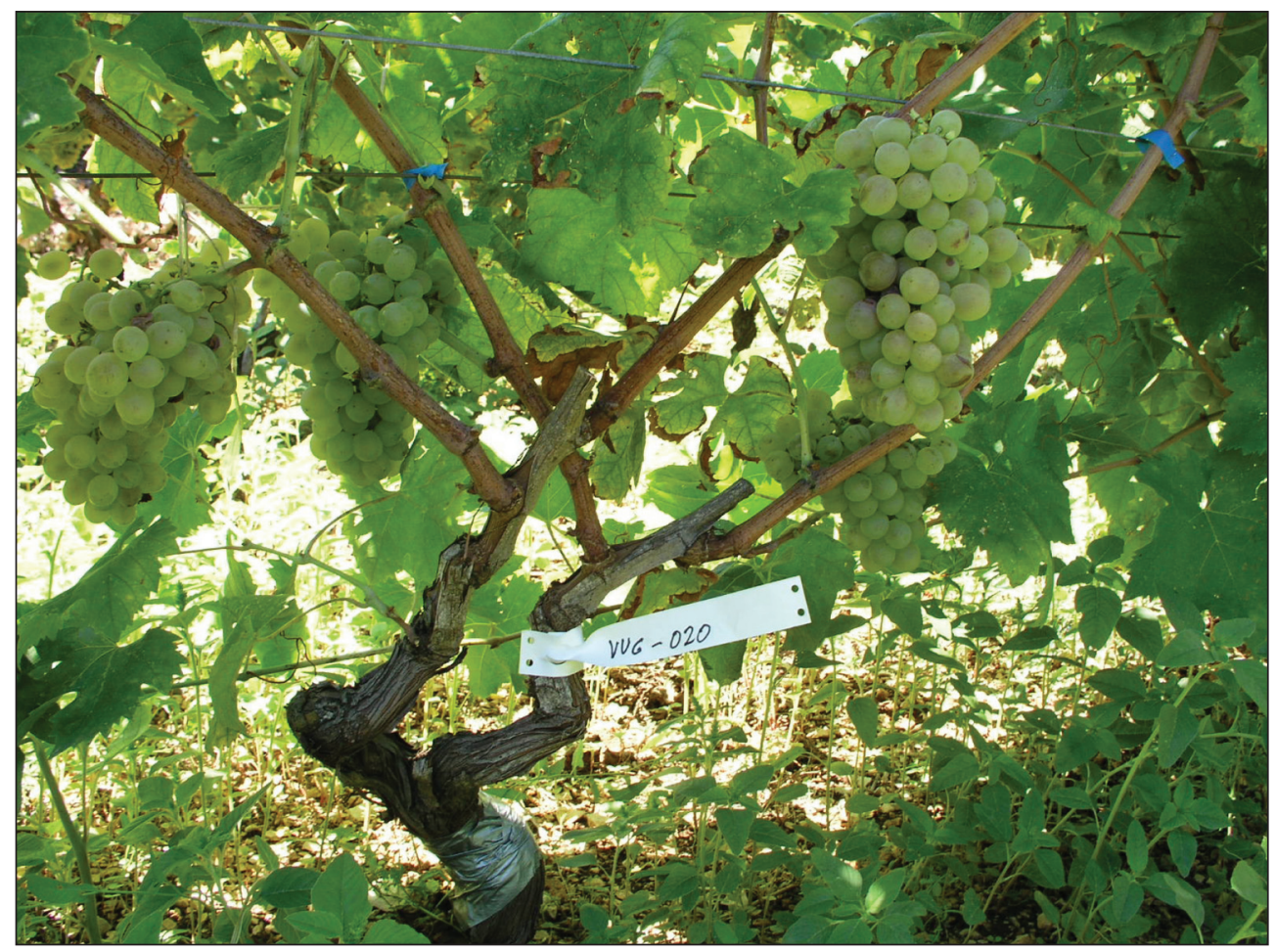

Slika 4: Jedan od izabranih klonskih kandidata cv. Vugava 


\section{Grapevine Intravarietal Variability Research in Croatia and Clonal Selection}

\section{Summary}

A high number of grapevine varieties have been traditionally grown in Croatia, most of them considered autochthonous. Because of the lack of systematic selection within them so far, it is supposed that a high level of intravarietal variability is present. The result of longterm growing of grapevine and vegetative propagation without systematic selection is high level of intravarietal variability. It is mostly caused by mutations, which can positively or negatively influence the growing characteristics of grapevine varieties. Clonal selection is a process of genotype (mutant) selection within variety populations, which are modified by some important variety characteristics. Clonal selection process is required in quality plant material production, with improved variety characteristics and guaranteed healthy conditions. Scientific researches of intravarietal variability and the improvement of clonal selection methods can highly contribute to the viticulture production development, and they are indirectly important for genetic resources preservation. This is essential for countries with high number of autochthonous varieties, in order to encourage their revitalisation process. In this paper, we give an overview of methods and recent research of intravarietal variability, as well as grape varieties improvement through clonal selection processes. Special attention is paid to Croatian grapevine research in the last ten years; the results point out a high level of intravarietal variability, and the necessity of clonal selection procedure for most of them.

Keywords: grapevine; intravarietal variability; clonal selection; autochthonous varieties.

Prof. dr. sc. Edi Maletić

Sveučilište u Zagrebu, Agronomski fakultet

Zavod za vinogradarstvo i vinarstvo

Svetošimunska cesta 25, 10000 Zagreb

emaletic@agr.hr 